\title{
The 2013 Ming K Jeang award for excellence in Cell \& Bioscience
}

Yun-Bo Shi

\begin{abstract}
Two research groups led by Yihong Ye of National Institute of Diabetes and Digestive and Kidney Diseases, National Institutes of Health, MD, USA and Dr. Lixin Wei of Medical Sciences Research Center, Renji hospital, School of Medicine, Shanghai Jiaotong University, Shanghai, China, won the 2013 Ming K Jeang Award for Excellence in Cell \& Bioscience.
\end{abstract}

\section{Editorial}

We are very pleased to announce that two research groups, who each published an outstanding research article in Cell E Bioscience in 2013, have been selected to receive the Ming K Jeang Award for Excellence in Cell $\mathcal{E}$ Bioscience. The Ming K Jeang Award for Excellence in Cell \& Bioscience was established in 2011 with a generous donation from the Ming $\mathrm{K}$. Jeang Foundation to honor outstanding research articles published in Cell $\mathcal{E}$ Bioscience, the official journal of the Society of Chinese Bioscientists in America (SCBA; www.scbasociety.org). A committee of Cell $\mathcal{E}$ Bioscience Editors, chaired by Dr. Chris Lau, considered all research articles published in the journal in 2013 to select the following two articles to receive the award [1,2].

Monoubiquitination of EEA1 regulates endosome fusion and trafficking.

Harish N Ramanathan, Guofeng Zhang, Yihong Ye

Cell \& Bioscience 2013, 3:24 (23 May 2013).

Autophagy lessens ischemic liver injury by reducing oxidative damage.

Kai Sun, Xuqin Xie, Yan Liu, Zhipeng Han, Xue Zhao, Ning Cai, Shanshan Zhang, Jianrui Song, Lixin Wei

Cell \& Bioscience 2013, 3:26 (10 June 2013).

Congratulations to these two groups of investigators for jobs well done!

We are looking forward to receiving contributions of outstanding research articles from the scientific community in 2014 and beyond.

\section{Acknowledgements}

I would like to thank Dr. Chris Lau and the other editors for reviewing and selecting the awardees. The opinions expressed in this Editorial are the author's personal views and do not necessarily reflect the views of his employer, the National Institutes of Health, USA.

Received: 20 February 2014 Accepted: 20 February 2014

Published: 24 March 2014

\section{References}

1. Ramanathan $\mathrm{HN}$, Zhang $\mathrm{G}, \mathrm{Ye}$ Y: Monoubiquitination of EEA1 regulates endosome fusion and trafficking. Cell \& Bioscience 2013, 3:24

2. Kai Sun K, Xie X, Liu Y, Han Z, Zhao X, Cai N, Zhang S, Song J, Wei L: Autophagy lessens ischemic liver injury by reducing oxidative damage. Cell \& Bioscience 2013, 3:26.

doi:10.1186/2045-3701-4-15

Cite this article as: Shi: The 2013 Ming K Jeang award for excellence in Cell \& Bioscience. Cell \& Bioscience 2014 4:15.

Correspondence: shi@helix.nih.gov

The National Institutes of Health, Bethesda, MD, USA

Submit your next manuscript to BioMed Central and take full advantage of:

- Convenient online submission

- Thorough peer review

- No space constraints or color figure charges

- Immediate publication on acceptance

- Inclusion in PubMed, CAS, Scopus and Google Scholar

- Research which is freely available for redistribution

Submit your manuscript at www.biomedcentral.com/submit
( BioMed Central

\section{Biomed Central}

(c) 2014 Shi; licensee BioMed Central Ltd. This is an Open Access article distributed under the terms of the Creative Commons Attribution License (http://creativecommons.org/licenses/by/4.0), which permits unrestricted use, distribution, and reproduction in any medium, provided the original work is properly credited. The Creative Commons Public Domain Dedication waiver (http://creativecommons.org/publicdomain/zero/1.0/) applies to the data made available in this article, unless otherwise stated. 